\title{
Evaluation of a tidal flat sediment nourishment as estuarine management measure
}

\author{
J. van der Werf ${ }^{\mathrm{a}, ~ *}$, J. Reinders ${ }^{\mathrm{a}}$, A. van Rooijen ${ }^{\mathrm{a}}$, H. Holzhauer ${ }^{\mathrm{a}}$, T. Ysebaert ${ }^{\mathrm{b}, \mathrm{c}}$ \\ a Deltares, P.O. Box 177, 2600 MH Delft, The Netherlands \\ ${ }^{\mathrm{b}}$ Institute for Marine Resources and Ecosystem Studies (IMARES), P.O. Box 77, 4400 AB Yerseke, The Netherlands \\ ${ }^{\mathrm{c}}$ Royal Netherlands Institute for Sea Research (NIOZ), Korringaweg 7, 4401 NT Yerseke, The Netherlands
}

\section{A R T I C L E I N F O}

\section{Article history:}

Received 14 November 2014

Received in revised form 9 June 2015

Accepted 14 June 2015

Available online 27 June 2015

\section{Keywords:}

Eastern Scheldt

Estuarine management

Morphological and ecological monitoring

Sediment nourishment

Tidal flat

\begin{abstract}
A B S T R A C T
The tidal flats in the Eastern Scheldt tidal basin (The Netherlands) are eroding as a result of the construction of the storm surge barrier. These intertidal areas are important foraging grounds for birds and therefore it is important to mitigate the negative effects of erosion. As a pilot, a small part ( $20 \mathrm{ha}$ ) of the Galgeplaat tidal flat in the middle of the Eastern Scheldt was nourished with $130,000 \mathrm{~m}^{3}$ of sediment in 2008. This paper investigates this tidal flat nourishment using a large set of morphological and ecological monitoring data from 2008 to 2012. The nourishment proved effective in mitigating the negative effects of tidal flat erosion. The elevated tidal flat provides a foraging area for birds that is available for a longer period. The nourished area was relatively stable, giving time for the recovery of benthic macrofauna such that birds can benefit from the longer exposure time. Therefore, we conclude that sediment nourishments are an effective management measure to counteract the negative consequences of tidal flat erosion in the Eastern Scheldt, and have potential for other estuaries worldwide.
\end{abstract}

๑) 2015 Elsevier Ltd. All rights reserved.

\section{Introduction}

Tidal flats are common along shallow-water coastlines and estuaries worldwide, accumulating fine-grained sediments on gently sloping beds, forming the basic structure upon which coastal wetlands build (Dyer et al., 2000). The morphology of tidal flats is a complex outcome of tides, waves, sediment properties and ecological processes (Le Hir et al., 2000; Friedrichs, 2011). Human pressures (e.g. land reclamation, dredging, pollution, fisheries) have resulted in a worldwide decline in the extent and health of many intertidal coastal ecosystems (Lotze et al., 2006; Airoldi and Beck, 2007). Consequences of the loss of these intertidal habitats are manifold as they are very productive, diverse systems that provide several crucial ecosystem goods and services such as provision of habitat for bird life (Costanza et al., 1997; Barbier et al., 2011). Recently, the role of tidal flats in coastal protection and adaptation is increasingly recognized (Temmerman et al., 2013; Bouma et al.,

\footnotetext{
* Corresponding author.

E-mail addresses: Jebbe.VanDerWerf@deltares.nl (J. van der Werf), Jose. Reinders@deltares.nl (J. Reinders), Arnold.VanRooijen@deltares.nl (A. van Rooijen), Harriette.Holzhauer@deltares.nl (H. Holzhauer), Tom.Ysebaert@wur.nl (T. Ysebaert)
}

2014). They act as a natural buffer for flood protection and erosion control by inducing wave and tidal energy dissipation, and as a sediment trap, thus helping to build land seawards. The conservation and restoration of tidal flat ecosystems is a challenging coastal management issue, because of the complex ecomorphological behavior of these ecosystems and the lack of proper management guidelines.

In case of the Eastern Scheldt, a coastal bay in the southwest of The Netherlands (Fig. 1), several measures to mitigate the loss of tidal flats due to ongoing erosion are currently being proposed and experimented with. The Eastern Scheldt is a good example of a coastal system that underwent large physical and ecological changes due to a system-wide human interference (Nienhuis and Smaal, 1994; Cozzoli et al., 2014). As a response to the severe storm surge in 1953, the Dutch Government initiated the Delta works. These included the construction of a series of dams to close off most tidal basins in the southwest of The Netherlands to ensure future safety against flooding of the hinterland. For most of the inlets an impermeable dam was constructed, resulting in the complete loss of the estuarine nature, including large areas of tidal flats and salt marshes. After public protest the original plan for one of the tidal inlets, the Eastern Scheldt, was changed in the 1970s; a permeable barrier was constructed instead of a dam. This storm 

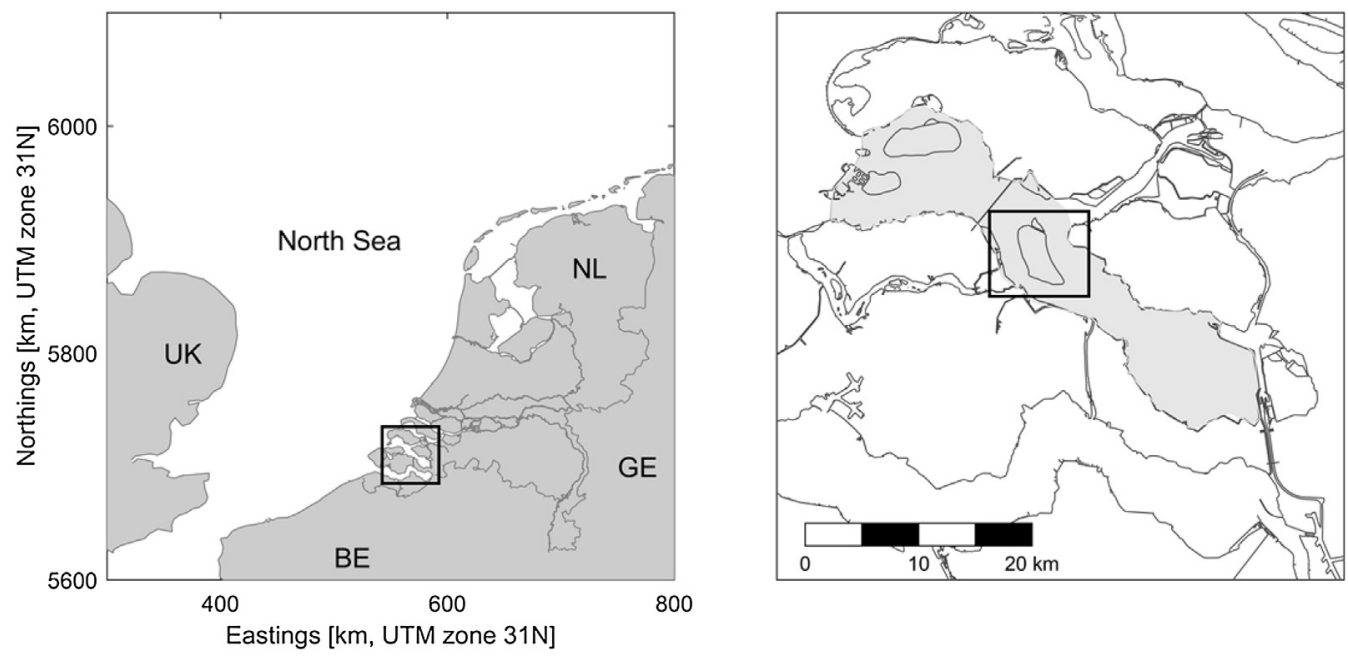

Fig. 1. Left panel: Eastern Scheldt located in the southwestern part of The Netherlands. Right panel: Galgeplaat tidal flat located in the center of the Eastern Scheldt.

surge barrier allows the tide to enter the estuary under normal conditions, while it can be closed during storm conditions (approx. once per year). The barrier reduces water levels within the estuary, providing better protection of the hinterland against flooding. In this way the basin remains salt and still experiences tidal flow, maintaining its valuable habitats for estuarine flora and fauna.

Although the barrier allows for tidal exchange, it does reduce the tidal amplitude and flow significantly. The average tidal range decreased from $3.70 \mathrm{~m}$ in 1984 to $3.25 \mathrm{~m}$ in 1987, the tidal volume from 1.3 to 0.9 million $\mathrm{m}^{3}$, and the average tidal velocity in the channels from 1.2 to $0.8 \mathrm{~m} / \mathrm{s}$ (Ten Brinke et al., 1994). It is commonly believed (see e.g. Eelkema, 2013) that tidal currents transport sediment from the channels towards the tidal flats and subsequently build them up, whereas locally-generated wind waves tend to have an eroding effect. Due to the decrease in tidal flow, the building-up of the flats has reduced. Consequently, the tidal flats in the Eastern Scheldt are eroding since the construction of the storm surge barrier. At the same time sediment accumulates in the tidal channels due to the reduced flow velocities; the cross-section channel area is too large given the reduced tidal prism. This sediment demand would be less of a problem if the Eastern Scheldt basin could receive sediment from the ebb-tidal delta. However, the storm surge barrier blocks most of the sediment import into the basin (Ten Brinke, 1993).

The construction of the storm surge barrier has thus disturbed the dynamic morphological equilibrium of the Eastern Scheldt basin due to the reduced tidal volume. This equilibrium can only be restored if the tidal channels have filled up and reduced in size. Koshiek et al. (1987) estimated that the tidal channels require approx. 500 million $\mathrm{m}^{3}$ of sediment to regain equilibrium. Since the tidal flats can only offer around 160 million $\mathrm{m}^{3}$ this would mean that on the long term the tidal flats in the Eastern Scheldt would disappear (Van Zanten and Adriaanse, 2008). This reduction of intertidal area is clearly visible in the field. Van Zanten and Adriaanse (2008) showed that the total intertidal area reduced from $113 \mathrm{~km}^{2}$ in 1985 (before the closure) to $104 \mathrm{~km}^{2}$ in 2001 (after 15 years). This corresponds to a yearly loss of intertidal area of approx. $0.5 \mathrm{~km}^{2}$ or 50 ha.

Tidal flats in the Eastern Scheldt are especially important as foraging grounds for birds. Internationally important numbers of water bird species, especially waders, reside in the Eastern Scheldt. For this reason the Eastern Scheldt is part of the European
Natura2000 network, protected under the European Bird and Habitat Directives. It is expected that if tidal flats would further diminish (both in area and the period of time it is exposed for birds to forage for food), the number of birds will decline in the near future (De Ronde et al., 2013). Therefore, Rijkswaterstaat (part of the Dutch Ministry of Infrastructure and Environment) identified possible measures to mitigate tidal flat erosion (Van Zanten and Adriaanse, 2008). Worldwide experience with mitigating erosion of tidal flats is minimal. Therefore, pilot projects were launched in order to further investigate their effectiveness and impact. One of these pilots is the nourishment of sediment on the tidal flat Galgeplaat in the middle of the Eastern Scheldt (see Fig. 1).

The main aim of the pilot was to investigate whether tidal flat nourishments are a good management measure to maintain valuable intertidal habitat for bird life. For these birds abundance and availability of benthic macrofauna (i.e. macrobenthos), their main food source, are important. The time food is available to waders is to a large extent determined by the exposure time of the tidal flats as they can only forage on an exposed tidal flat. A tidal flat nourishment initially increases exposure time, and therefore potential foraging time, but at the same time kills all benthos present when the sediment layer is larger than $0.5 \mathrm{~m}$ (Baptist et al., 2009). It is hypothesized that over time benthic life will recover which favors the waders, but at the same time exposure time will decrease due to the ongoing erosion of the nourishment. Therefore, the effectiveness of this measure for bird life depends on both the benthos recovery time and the life-time of the nourishment. This paper investigates this hypothesis on the basis of a large set of morphological and ecological monitoring data. This will result in recommendations on the suitability of sediment nourishments as an estuarine management measure to counteract the negative effects of tidal flat erosion due to distortion of the sediment cycle.

\section{Material and methods}

\subsection{The Eastern Scheldt}

The Eastern Scheldt is an elongated tidal basin of approx. $50 \mathrm{~km}$ in length and a surface area of $350 \mathrm{~km}^{2}$, located in the southwestern part of The Netherlands (see Fig. 1). In ancient times, the Eastern Scheldt estuary was the mouth of the Scheldt River, which originates in the North of France and flows northward through Belgium, 
until in the Middle Ages the Western Scheldt took over this function. The evolution of the Eastern Scheldt since then has been largely affected by human interferences such as land reclamation and the construction of dikes and dams. The historical morphological evolution of the Eastern Scheldt estuary is described in detail by Eelkema (2013). Nowadays, the Eastern Scheldt has an average freshwater load of $25 \mathrm{~m}^{3} / \mathrm{s}$ and is mesotrophic with an average salinity of 30 (Nienhuis and Smaal, 1994). Sections 3.1 and 3.2 provide more information on the hydrodynamic conditions in the Eastern Scheldt.

\subsection{The Galgeplaat}

The Galgeplaat is located in the middle of the Eastern Scheldt (see Figs. 1 and 2) and is one of the largest sandy shoals in the tidal basin. It is bound by the tidal channels Engelsche Vaarwater to the West and the shallower Brabantsche Vaarwater and Witte Tonnen Vlije to the East. Over the past decades the Galgeplaat has strongly suffered from erosion. According to Van Zanten and Adriaanse (2008), its intertidal area reduced from 1.00 to $0.96 \mathrm{~km}^{2}$ between 1985 and 2001. At the same time the average bed level reduced from NAP $-0.32 \mathrm{~m}$ to NAP $-0.65 \mathrm{~m}$ (NAP is the Dutch Ordnance Datum almost corresponding with mean sea level). This gives an average erosion of about $0.02 \mathrm{~m} /$ year corresponding to a total sediment loss of 3.8 million $\mathrm{m}^{3}$ above average low water level between 1985 and 2001. According to the more recent study of Santinelli and De Ronde (2012), the average erosion of the Galgeplaat is about $0.01 \mathrm{~m} /$ year.

\subsection{The nourishment pilot}

The nourishment on the Galgeplaat was constructed in the period July-September 2008 with sediment obtained from maintenance dredging in the Brabantsche Vaarwater and Witte Tonnen Vlije. In total about $130,000 \mathrm{~m}^{3}$ of sediment was nourished in an area of approx. $200,000 \mathrm{~m}^{2}$, resulting in an average nourishment height of $0.65 \mathrm{~m}$. The initial bed level at the site varied roughly between NAP -0.8 and $-0.5 \mathrm{~m}$; due to the nourishment bed levels were increased to in between NAP -0.6 and $+0.4 \mathrm{~m}$. The resulting morphology was clearly not spatially uniform with the highest bed levels on the northern part of the nourished area (see Fig. 3).

An increase in suspended particulate matter concentration during the construction phase had to be avoided because of nearby commercial mussel beds. Therefore, the construction of the nourishment started with the building of a ring dike of about $1 \mathrm{~m}$ high, which was subsequently filled with sediment during a tidal window of -0.60 till $0.40 \mathrm{~m}$ NAP. This ring dike contained an opening in the direction of the tidal channel to steer the transport direction of fine sediment. Together with the tidal window, this allowed for a controlled nourishment construction.

Since the sediment was taken from the tidal channel, the median grain size at the nourishment site increased from $D_{50}=0.19-0.22 \mathrm{~mm}$ on average due to the nourishment. The percentage of mud $(<0.063 \mathrm{~mm})$ remained more or less stable and was at all measurement locations less than $7 \%$.

\subsection{Monitoring}

The morphological development of the entire nourishment was initially monitored every month using $25 \mathrm{~m}$ spaced single beam surveys, and from September 2009 every three months. Since December 2009 these measurements were replaced by more accurate Real Time Kinematic (RTK) measurements. To monitor the detailed bed level changes these data were supplemented by a set of monthly Sedimentation Erosion Trend (SET) measurements on

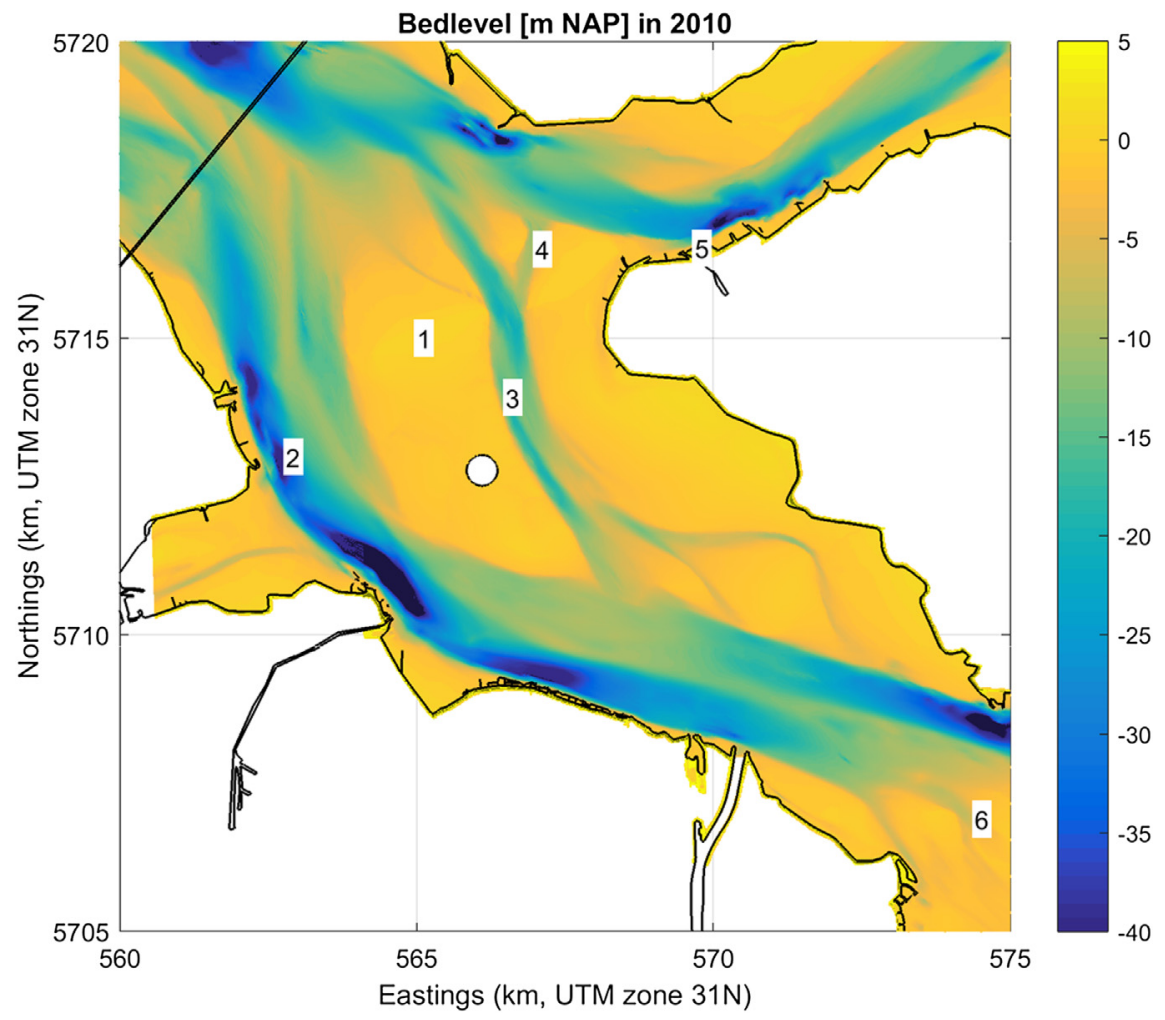

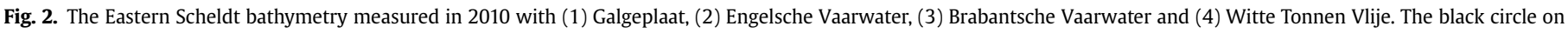
the Galgeplaat indicates the nourishment site. (5) Indicates the location of wind station Stavenisse and (6) the location of tidal station Yerseke. 

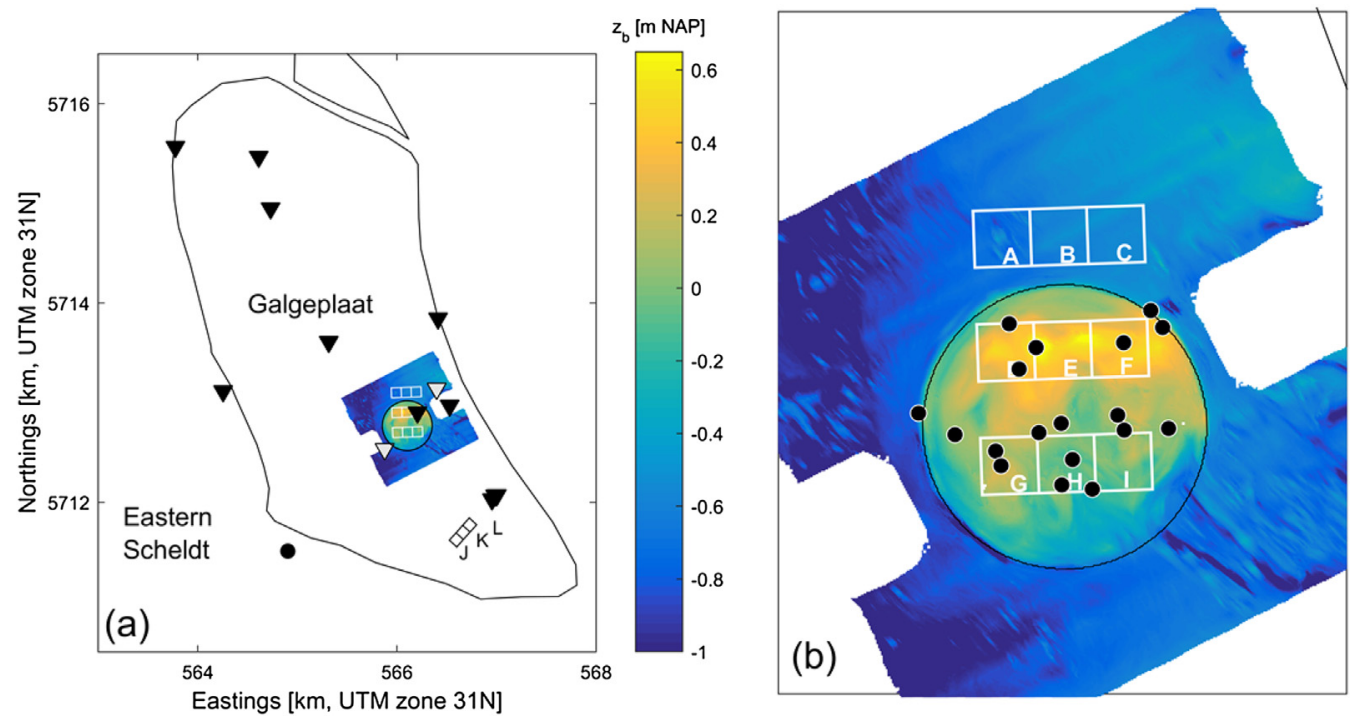

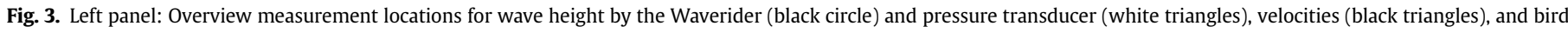
counting areas J-L. Right panel: initial bathymetry of nourishment and the benthos sampling sites and bird counting areas A-I.

14 locations on and in close vicinity to the nourishment. In addition, the data were compared to three-monthly RTK measurements along 5 pre-defined transects across the nourishment.

Wave heights were measured in the main tidal channel using a Waverider and on the tidal flat using pressure transducers. Current velocities were measured both in the channels and on top of the tidal flat using Acoustic Doppler Current Profiler (ADCP) and Aquadops (see Fig. 3).

To assess the recolonization of the nourishment by macrobenthos over time, sediment cores were taken and analyzed. This included 10 benthos sampling locations on the nourishment site and 10 control (i.e. undisturbed) locations just outside the nourishment site. From 2009 the number of sampling sites on the nourishment was increase to 18 (see Fig. $3 \mathrm{~b}$ ) to better monitor the spatial variation.

Three $0.3 \mathrm{~m}$ deep sediment cores (with an area of $50 \mathrm{~cm}^{2}$ ) were taken within a $1 \mathrm{~m}$ radius per sampling location, and subsequently sieved on a $1 \mathrm{~mm}$ mesh. The samples were fixated with $\mathrm{pH}$-neutral formaldehyde after which the macrobenthos was classified to the lowest taxonomic level possible. Next, the density and biomass of each species was determined for every sampling site. For grain size analysis, small sediment cores were taken at each sampling site, using a tube with a diameter of $1 \mathrm{~cm}$, which was pushed $3 \mathrm{~cm}$ in the sediment. The grain size distribution was determined using a Malvern laser diffraction system. In this paper only the general trends in species richness, density and biomass of the macrobenthos are discussed; a more detailed analysis on the temporal and spatial recolonisation patterns of the macrobenthos will follow in a later paper.

For each sighted bird the behavior (foraging or not) was registered every 15 min during low tide on two consecutive days in October, at the nourishment $(3 \times 2$ plots of $100 \times 100 \mathrm{~m}$, see Fig. $3 \mathrm{~b})$ and at two reference areas $(3 \times 2$ plots of $100 \times 100 \mathrm{~m}$ each). Observations took place yearly between 2007 and 2012, except for the year 2008. The first reference area is located just north of the nourishment and has the same elevation as the location of the nourishment prior to the nourishment. The second reference area was located southeast of the nourishment, with a bed level similar to that at the nourishment site after the nourishment was placed (Fig. 3a). This second reference area was included from 2011 onwards.
An overview of the measurements relevant for this study is given in Table 1. More information on the Galgeplaat nourishment monitoring can be found in Van der Werf et al. (2013).

\section{Results}

\subsection{Hydrodynamics}

The tidal range at measuring station Yerseke, located near the Galgeplaat (see Fig. 2), is $3.2 \mathrm{~m}$ with mean low water at NAP $-1.3 \mathrm{~m}$ and mean high water at NAP $+1.9 \mathrm{~m}$. The M2 tidal component is dominant which means every $12.4 \mathrm{~h}$ the Galgeplaat is flooded and exposed.

The wind rose for the period 2008 to 2012, based on data from the nearby station Stavenisse (see Fig. 2), shows that winds predominately came from the Southwest, although also relative high wind speeds from the Northwest occurred (Fig. 4). The average wind speed was $6 \mathrm{~m} / \mathrm{s}$ corresponding to $4 \mathrm{Bft}$. The maximum wind speed measured in the considered period was $23 \mathrm{~m} / \mathrm{s}$, i.e. $9 \mathrm{Bft}$.

In the period October 2008-September 2012 a total number of 17 storm events were identified, which were defined as wind speeds larger than $17 \mathrm{~m} / \mathrm{s}$ ( $8 \mathrm{Bft}$ and higher) occurring for a period of at least $0.5 \mathrm{~h}$. As for normal conditions, the dominant wind direction under storm conditions is southwesterly.

The Eastern Scheldt storm surge barrier blocks most of the offshore incoming waves. Hence the majority of the short waves are locally wind-generated. Wave records indicated that in the prevailing SW-NW winds the average significant wave height decreases from about $0.4 \mathrm{~m}$ near the mouth to $0.1 \mathrm{~m}$ in the landward part of the Eastern Scheldt with a dominant wave energy flux from the southwest (Louters et al., 1998).

According to the Waverider measurements in the channel to the southwest of the Galgeplaat (Fig. 3a, black circle), the significant wave height nearby the Galgeplaat varied between 0.4 and $0.8 \mathrm{~m}$ and the spectral peak period between 2.5 and $3.5 \mathrm{~s}$ during the storm events. The waves are very much damped on the tidal flat such that this height reduced to $0.1-0.2 \mathrm{~m}$ on the Galgeplaat nourishment site (see Van der Werf et al., 2012).

Under normal wind conditions, the current measurements show peak velocities of about $0.5 \mathrm{~m} / \mathrm{s}$ on the Galgeplaat during ebb tide. At the nourishment site, velocities were somewhat smaller, 
Table 1

Overview of the measurements dedicated to the Galgeplaat nourishment.

\begin{tabular}{|c|c|c|c|c|}
\hline Parameter & Measurement type & Period & Frequency & Spatial coverage \\
\hline \multirow[t]{3}{*}{ Bed level } & RTK (transects) & May 2008-Nov 2012 & every 3 months & 5 profiles \\
\hline & SB/RTK & May 2008-Nov 2012 & every $1-3$ months & nourishment site \\
\hline & SET & May 2008-Nov 2012 & monthly & 14 locations \\
\hline \multirow[t]{2}{*}{ Waves } & Waverider & May 2008-Jun 2011 & continuous & 1 location \\
\hline & Pressure Transducer & May 2008-Apr 2011 & every $1-2$ months & 2 locations \\
\hline \multirow[t]{3}{*}{ Velocity } & ADCP (channel) & Oct 2008-Nov 2008 & every 2 months & 3 locations \\
\hline & ADCP (tidal flat) & May 2008-Apr 2011 & every $1-2$ months & 4 locations \\
\hline & Aquadop (tidal flat) & Sep 2010-Mar 2011 & every $2-3$ months & 6 locations \\
\hline Benthos & Core sampling & $2008-2011$ & Yearly (October) & $\begin{array}{l}10 / 18 \text { nourishment } \\
10 \text { control }\end{array}$ \\
\hline Birds & Counting & 2007-2012 & Yearly (October) & $9 / 12$ areas of $100 \times 100 \mathrm{~m}$ \\
\hline
\end{tabular}

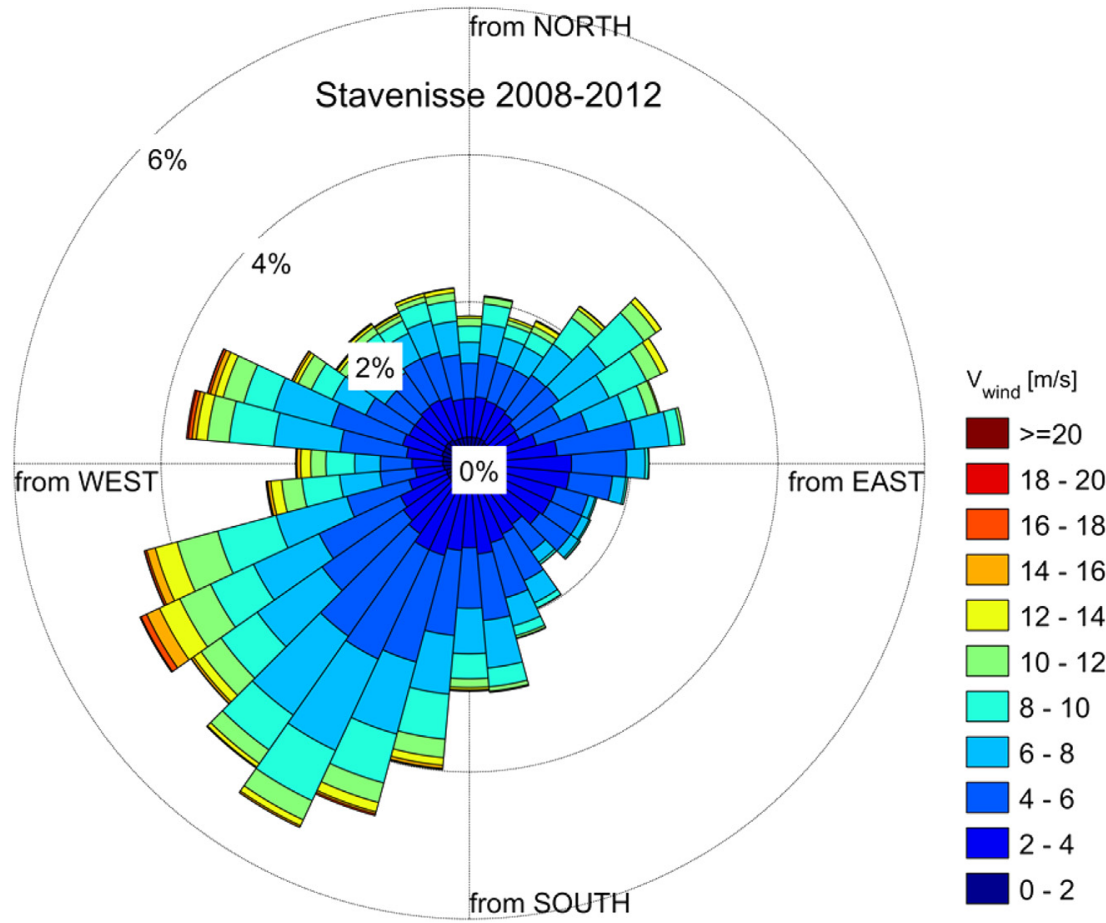

Fig. 4. Wind rose on the basis of 2008-2012 data measured at the station Stavenisse.

while current velocities reached $0.7-0.9 \mathrm{~m} / \mathrm{s}$ in the tidal channels (see Van der Werf et al., 2012). The nourishment site is only flooded a few hours per tide. The tidal current is directed to the South during flood. It then rotates clockwise to become north-directed during ebb tide. The current is clearly ebb-dominant with larger velocities to the North during the ebb phase of the tide (see Van der Werf et al., 2013).

\subsection{Morphology}

The largest morphological changes occurred during the first year after the nourishment construction: the highest part of the nourishment was flattened and bed level gradients became smaller resulting in a smoother bathymetry (Fig. 5). Hereafter the morphological changes were relatively small and the nourishment appears to be stable.

The higher, northern parts of the nourishment have eroded between 2008 and 2012 with a maximum of about $0.5 \mathrm{~m}$ (Fig. 6). Furthermore, a relatively strong sedimentation (about $0.5 \mathrm{~m}$ ) along the northern nourishment edge is observed. However, most parts of the measured area were relatively stable with only $0.1-0.2 \mathrm{~m}$ bed level change.
These morphological changes suggest a net sediment transport directed towards the North. However, this only applies when sediment transport is locally determined. This is not necessarily the case for suspended sediment transport, as it is possible that the sediment along the northern edge of the nourishment originated from other parts of the Galgeplaat. However, it is expected that these horizontal advection effects of sediment are not very important, given the typical sediment grain size and current velocity at the nourishment site.

Between October 2008 and September 2012 the sediment volume within the (initial) nourishment contour decreased with about $13,000 \mathrm{~m}^{3}$ which equals to about $10 \%$ of the initial nourishment volume (Fig. 7). This corresponds to an average erosion of $1.5-2.0 \mathrm{~cm} /$ year. The nourishment sediment stayed relatively close to the initial contour (see Fig. 6). It was found that 11,000 of the $13,000 \mathrm{~m}^{3}$ of sediment that was eroded from the nourishment stayed within $50 \mathrm{~m}$ of the initial contour. This means that only a small percentage was transported further away. Furthermore, there appears to be a seasonal effect, with sedimentation during the relatively calm wind conditions in summer and erosion during the relatively more stormy wind conditions in winter.

Cronin (2012) studied the Galgeplaat nourishment using a 

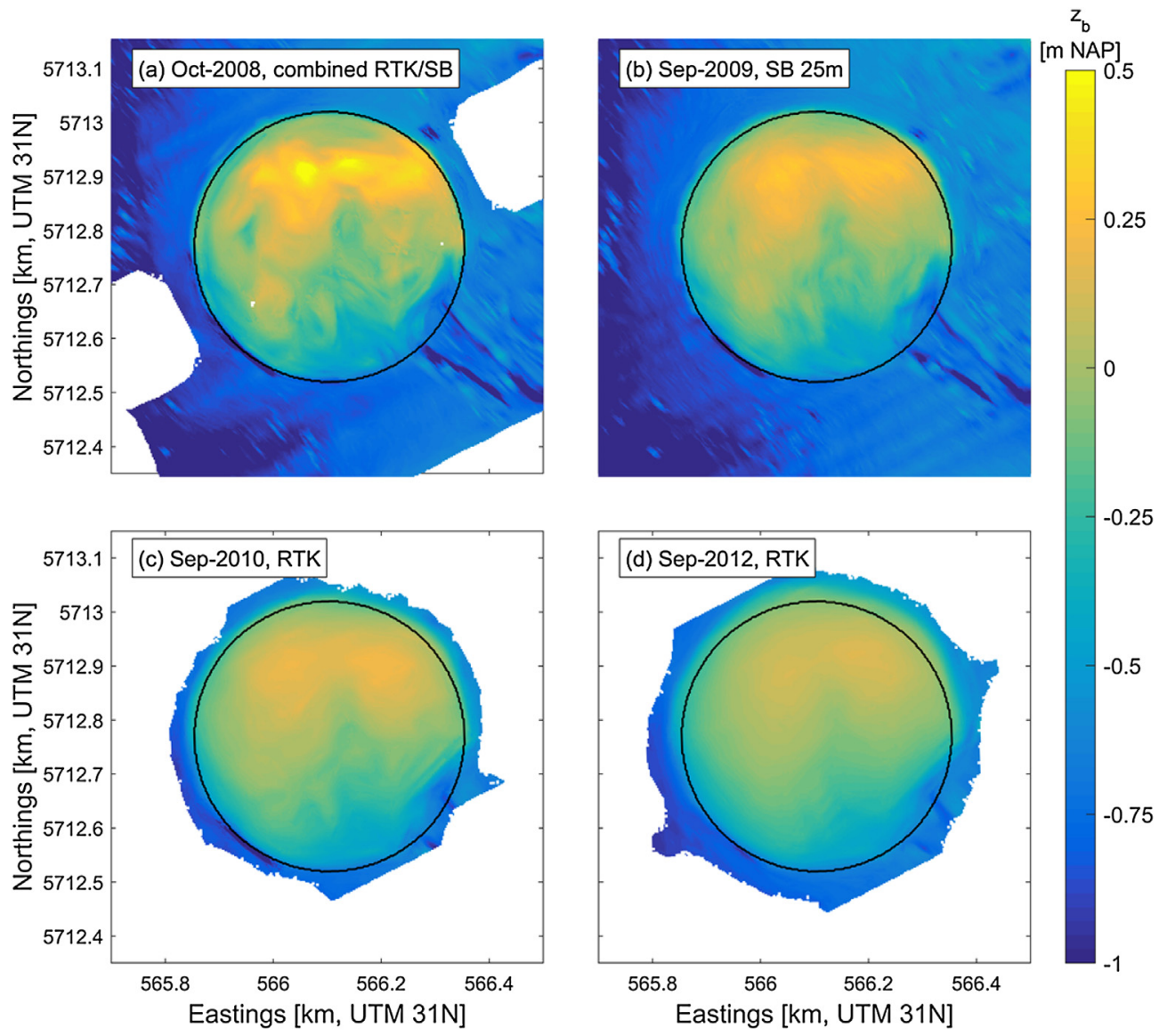

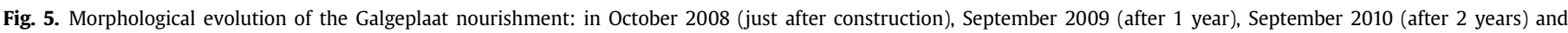
September 2012 (after 4 years).

depth-averaged (2DH) Delft3D model including flow, waves, sand transport and morphological changes. The model was calibrated and validated using the above-described field data. Cronin (2012) showed that the locally generated waves play an important role in the transport of sediments around and on the intertidal flats, and thus also on the morphological evolution of the Galgeplaat nourishment. This is similar to the conclusions drawn by Das (2010) using an earlier version of this Delft3D model. According to Das (2010), sediment movement is limited during normal conditions, while severe erosion of the Galgeplaat occurred during storm conditions. During storm conditions wave breaking brings sediment into suspension, which is then transported by the currents driven by the wind, wave and tide.

These modeling studies and the hydrodynamics described in Section 3.1 support that the observed morphological change of the Galgeplaat nourishment is due to the combined effect of waves and currents. The sediment is mobilized by wave breaking and subsequently transported by the current, which has a dominant northern direction due to tidal asymmetry and the pre-dominantly southwesterly winds.

\subsection{Exposure time}

The nourishment changed the local bathymetry such that the nourished area is longer exposed during low tide. This can be expressed through the exposure time, i.e. the percentage of time a location is exposed. This is an important ecological indicator because on the one hand birds have more time to forage in case of higher exposure duration, but on the other hand changes in exposure time might affect benthic community structure.

The highest macrobenthic biomass in intertidal areas in the Eastern Scheldt is generally present at a daily exposure time between 20 and 40\% (Troost and Ysebaert, 2011), which corresponds to an exposure duration of 5-10 h/day. Above an exposure time of $60 \%$ per day, biomass decreases considerably. However, several bird species need more time to forage; up to $14 \mathrm{~h}$ /day to fulfill in their energy requirements, especially in winter and during migration periods. Therefore, the intertidal areas with an exposure time of 40-60\% per day are also considered ecologically important (Zwarts et al., 2011).

The exposure time is computed using the bed level elevation data from the single beam/RTK surveys and water level data from a nearby tidal gauge nearby (Stavenisse). Fig. 8 shows that the largest part of the area was exposed $30-40 \%$ of the time prior to the nourishment. Just after the nourishment the exposure time increased significantly: about 11 ha were exposed more than $50 \%$ of the time and almost 1 ha more than $60 \%$ of the time. Four years after the nourishment the effect of the nourishment is still clearly visible: large parts of the area are exposed for $40-60 \%$ of the time.

\subsection{Macrobenthos}

The following description of the macrobenthos focuses on the total richness, density and biomass. More information per species can be found in Wijnhoven et al. (2012) and Van der Werf et al. (2013). 


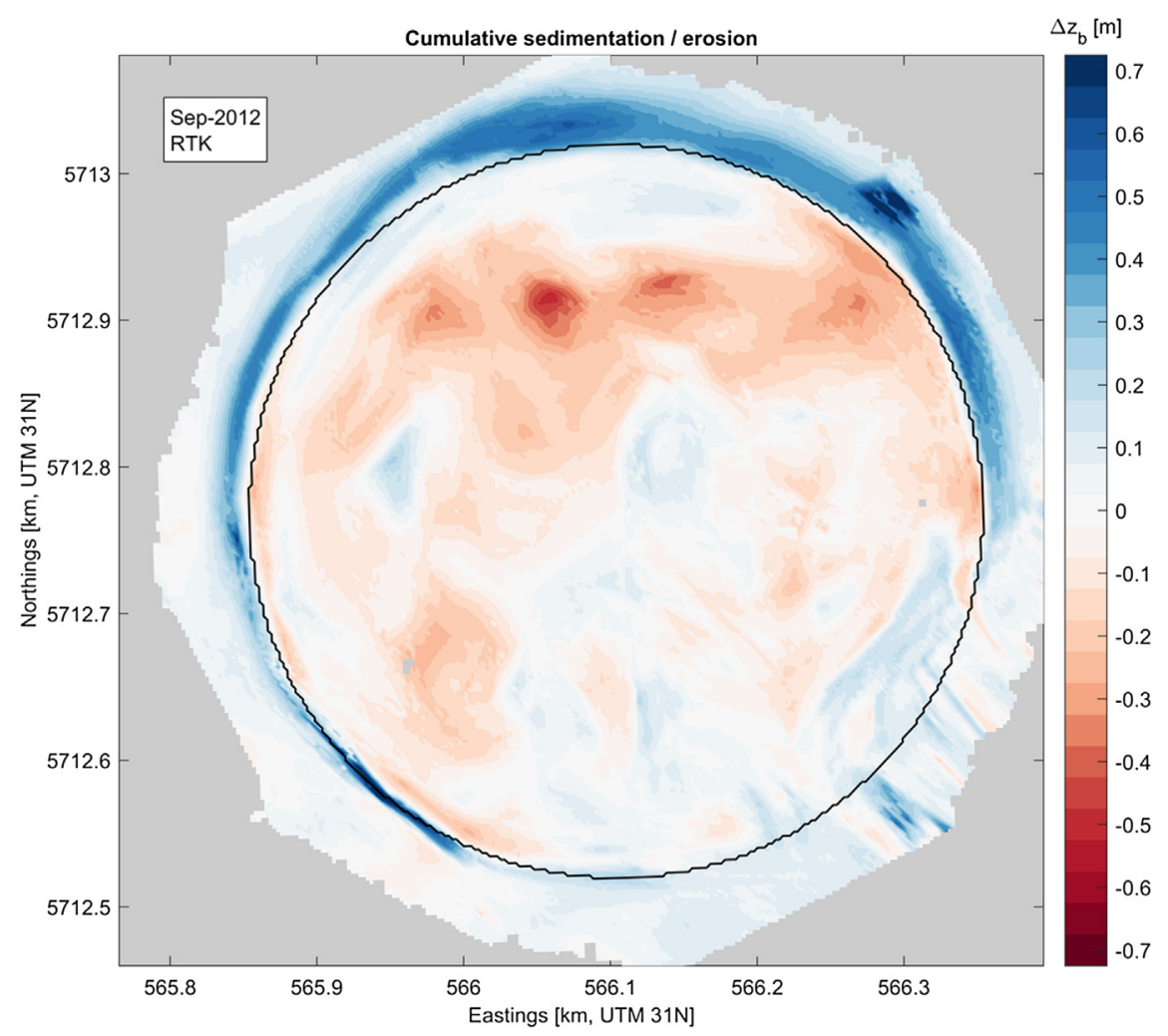

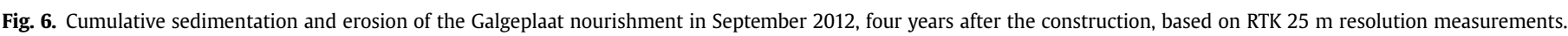

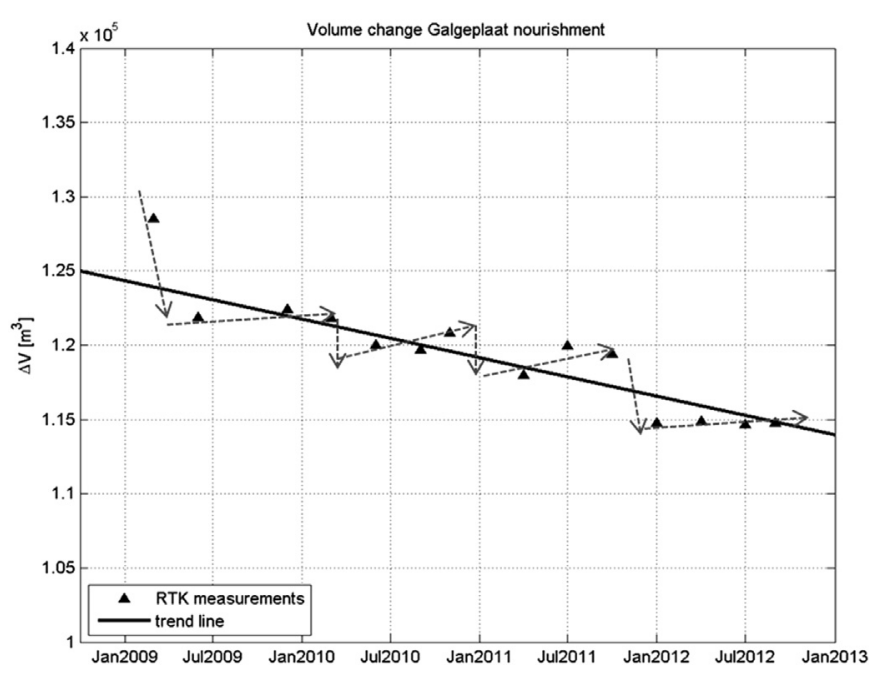

Fig. 7. Volume change within nourishment contour. The arrows indicate a possible seasonal effect.

Prior to the nourishment, in June 2008, total species richness was 47 in the surrounding, undisturbed area, whereas in the area where the nourishment was constructed species richness was lower (32) (Fig. 9). Average density and biomass were somewhat higher in the undisturbed area, although not significant (Fig. 9). In the following years, species richness and average biomass were somewhat lower in the undisturbed area, whereas average density showed a pronounced drop.

Compared to the undisturbed area, the macrobenthos on the nourishment showed a clear drop in species richness, density and biomass short after the construction (October 2008), after which a recovery was observed in the following years (Fig. 9). In October 2008 , average density and biomass were very low, representing only $2 \%$ and $8 \%$, respectively, of the values found in the undisturbed area. In 2009, species richness on the nourishment increased, due to settlement of new recruits of species like the lugworm Arenicola marina, the spionid Pygospio elegans, the cockle Cerastoderma edule and the Baltic tellin Macoma balthica. However, species richness and biomass in 2009 were still lower compared to the undisturbed area. With respect to density, higher values were observed on the nourishment site in 2009, due to the settlement of some opportunistic species like Pygospio elegans. From 2010 onwards the total species richness was similar on the nourishment compared to the undisturbed area. Despite the similar number of species, species composition still differed, with only $38-54 \%$ of the species observed both on the nourishment as in the undisturbed area.

Biomass increased slower than density, but reached higher values in October 2010 and October 2011 on the nourishment compared to the undisturbed area. This is due to the relatively high biomasses of newly settled cockles Cerastoderma edule on the nourishment area, which were not observed in the undisturbed area. In the undisturbed area, the number of Peringia ulvae decreased dramatically from October $2008\left(14,773 \mathrm{ind} / \mathrm{m}^{2}\right)$ to April $2009\left(1400 \mathrm{ind} / \mathrm{m}^{2}\right)$, and in the following years numbers never reached again these high values and the species was even absent from October 2010 onwards. On the contrary, Peringia ulvae became a dominant species (with respect to density) on the nourishment in summer and autumn. The reason for the decrease in numbers in the undisturbed area is unknown, although it is known that large yearto-year variations exist. The presence of Peringia ulvae on the nourishment is to be expected, as this species typically prefers the higher intertidal zone (Troost and Ysebaert, 2011).

With respect to the spatial variability of recolonisation on the nourishment, clear differences in biomass were observed. Sampling 

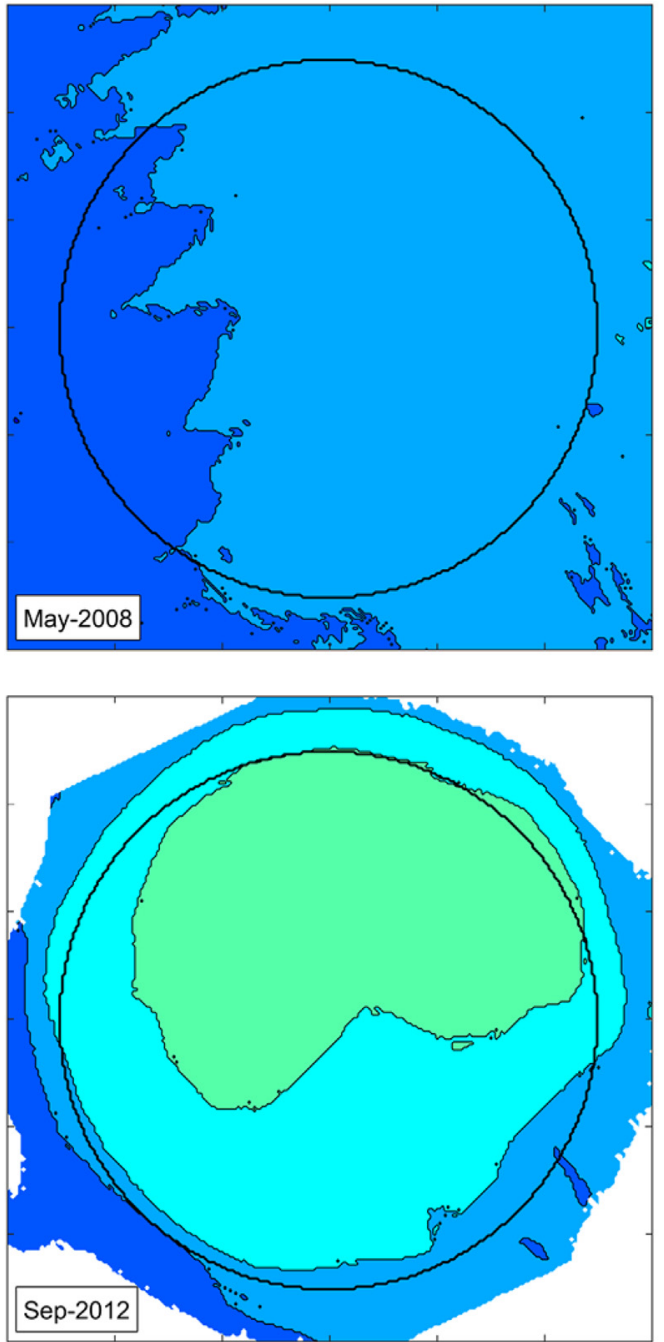

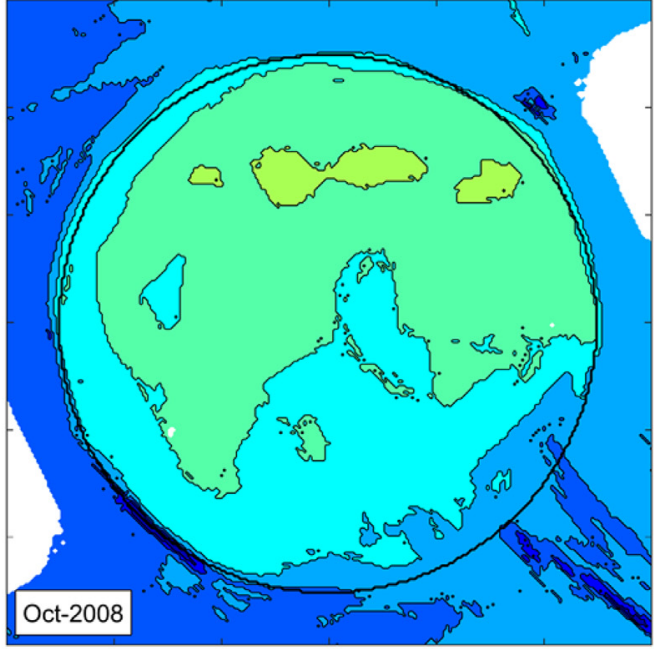

exposure duration [\% of time]

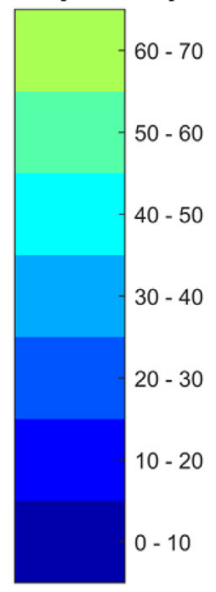

Fig. 8. Exposure time just before (May 2008), just after (October 2008) and 4 years after (September 2012) the nourishment.

locations with a lower elevation (i.e. the southern part of the nourishment) contained a higher macrobenthic biomass than locations on higher elevations (Fig. 10).

\subsection{Birds}

Over the period 2008-2012, the most abundant wader species on all counting locations were the Eurasian curlew (Numenius arquata) and the Oystercatcher (Haematopus ostralegus). Together these two species accounted for $93 \%$ of the foraging time observed in all locations. Other observed species included Grey plover (Pluvialis squatarola), Bar-tailed godwit (Limosa lapponica) and Dunlin (Calidris alpina).

Prior to the nourishment, the average foraging time for all species present per hectare was 2790 min per low tide (Fig. 11). This dropped to 550 foraging minutes on the nourishment area (average of the areas DEF and GHI) in 2009, while it increased to $3360 \mathrm{~min}$ at the reference area $A B C$. Two years after the construction of the nourishment the average number of foraging minutes on the nourishment had increased to 2270. In 2011, the number of foraging minutes increased at both the nourishment and the reference area.

In 2011 data were also collected at the additional reference area JKL which had the same bed elevation as the nourishment area. Here the average amount of foraging minutes per ha per low tide was 7840, which is almost double the number at the areas $A B C$ (other reference) and GHI.

Four years after the construction of the nourishment (2012), the average amount of foraging minutes on the nourishment was lower than the previous year, with 2120 min per ha per low tide. In the original reference area $(A B C)$, the foraging minutes slightly increased, while in the reference area with the same elevation level as the nourishment $(\mathrm{JKL})$, the number of foraging minutes was more than halved to 3270 . The high peak in 2011 for reference area JKL is caused by high numbers of Eurasian Curlews observed in counting area J. This is regarded as an anomaly and not as a true representative estimate of that year.

The number of foraging minutes is larger on the southern part of the nourishment (DEF) compared to the northern part (GHI). There seems to be a correlation with the spatial variation of macrobenthic biomass (see Fig. 10): the amount of foraging minutes is larger within the areas with relatively more biomass. This is illustrated in Fig. 12, which contains data of the average biomass and foraging minutes for the counting areas D-H for the years 2009-2011.

\section{Discussion and conclusions}

In 2008 a small part (20 ha) of the Galgeplaat tidal flat in the Eastern Scheldt tidal basin in the south-western part of The 

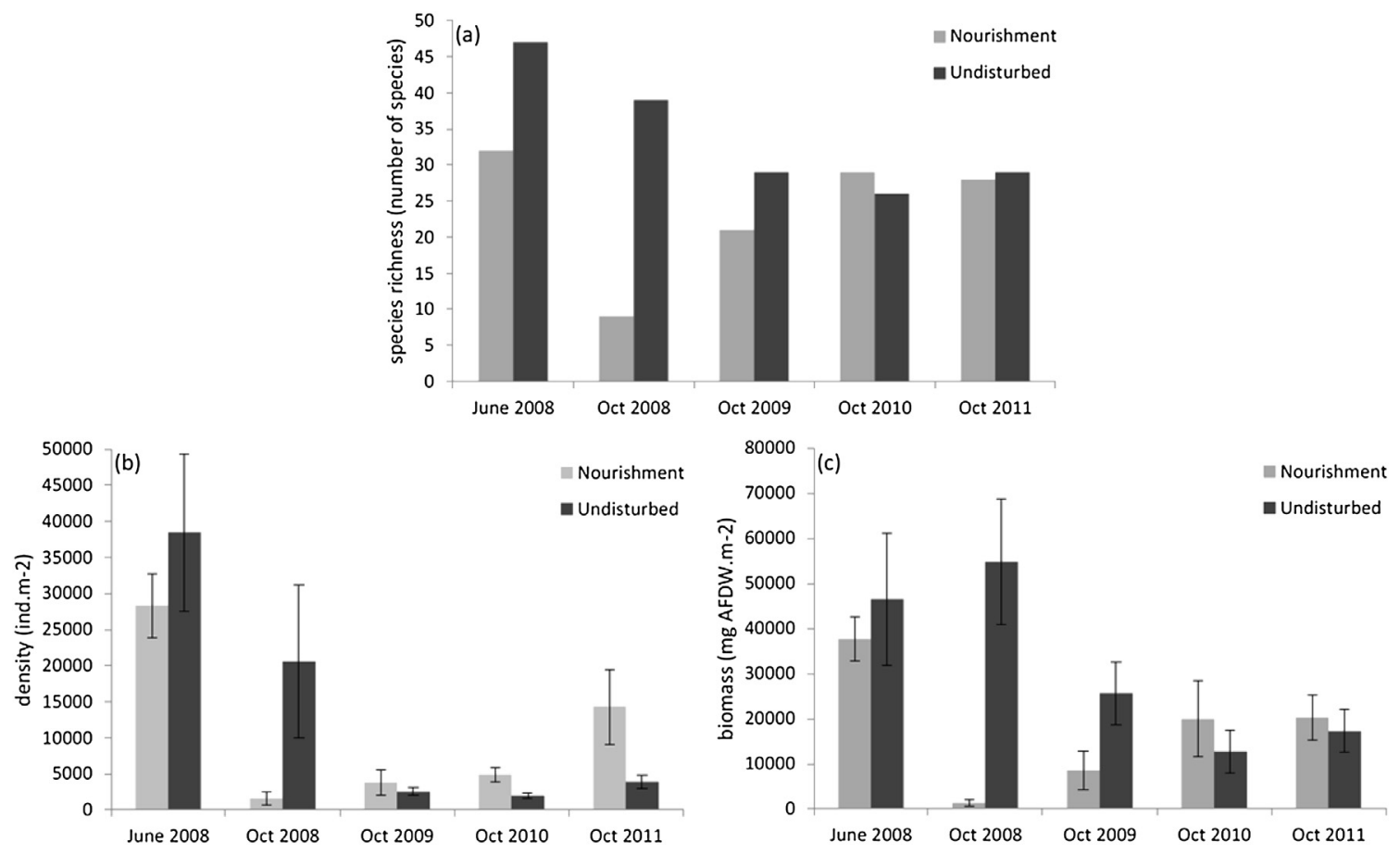

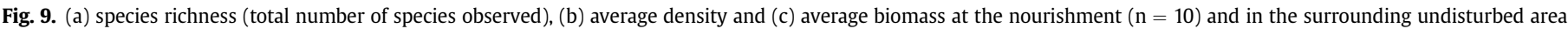

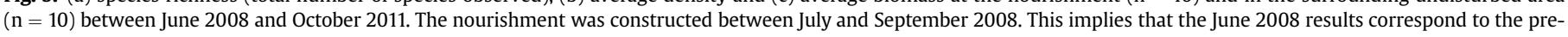
nourishment conditions.

Netherlands was nourished with about $130,000 \mathrm{~m}^{3}$ of sediment. This paper investigated whether tidal flat nourishments are a suitable management measure to conserve and restore valuable intertidal habitat for bird life on the basis of a large and unique set of morphological and ecological monitoring data (freely available through https://svn.oss.deltares.nl/repos/openearthrawdata/trunk/ rijkswaterstaat/Oosterschelde/Galgeplaat/).

The lifetime of the nourishment is one of the key factors for success. Four years after the construction of the nourishment, about $10 \%$ of the nourishment volume eroded from the initial nourishment contour. This corresponds to an average erosion rate of $2 \mathrm{~cm} /$ year, which is higher than the autonomous erosion of the southern part of the Galgeplaat of $0-0.5 \mathrm{~cm} /$ year. The nourishment thus eroded faster than its environment, which can be explained by its relatively high bed level inducing more sediment transport. Assuming an unchanged erosion trend, the expected lifetime of the nourishment is $30-40$ years. After this period the bed level at the nourishment site will be back at its pre-nourishment value. An important note is that there were no severe storm events in the considered period (2008-2012), and that the number of regular storms was limited. Severe storms are expected to have a large impact on the nourishment morphology, shortening the lifetime of the nourishment.

The largest part of the eroded volume stayed within $50 \mathrm{~m}$ of the nourishment contour. The erosion mainly concerned the highest northern part of the nourishment. This sedimentation-erosion pattern suggests a net sediment transport in northern direction. Supported by field data and previous modeling studies this transport direction can be explained by tidal asymmetry with a stronger northern ebb current and a predominantly southwestern wind direction, with breaking of locally-generated wind waves mobilizing the sediment. Erosion occurred during the more stormy winter periods, whereas the sediment seems to slowly accumulate during the calmer summer periods. This supports the hypothesis that the tides are mainly responsible for the built-up of tidal flats in the Eastern Scheldt, whereas wind and waves tend to break them down.

The nourishment enhanced the exposure time, which means that foraging time for birds has increased. However, this will only positively affect bird life when the benthic life has restored after being destroyed by the placement of the nourishment. Indeed, the macrobenthic community has largely recovered three years after the nourishment. Species richness, total density and total biomass are similar to the control area, but community composition is still different on the nourishment compared to the adjacent undisturbed bed. This recovery time of the benthic community is in line with other studies that found an average recovery time of four years after a shoreface nourishment (Van Dalfsen and Essink, 2001).

The benthic recovery on the nourishment showed a spatial variation with a relatively faster recovery on the lower parts. It is hypothesized that this spatial pattern is related to the soil moisture content. Moist soil contains a higher biomass than a dry soil (Borsje et al., 2012). Visual inspections indeed show that the higher parts of the nourishment are drier, while water remains at the lower parts during ebb tide creating permanently wet areas. Furthermore, the higher parts are more exposed to wind and waves which could negatively affect the benthic recovery.

The nourishment was constructed in order to conserve and restore the natural value of the area for Natura2000 bird species. This concerns mainly wader species that use the tidal flats to forage on at low tide, especially during migration and in winter. The Oystercatcher and Eurasian Curlew have partly returned to the nourished area. However, despite an increase in exposure time together with the recolonisation of the macrobenthic biomass, other waders such as Red Knot (Calidris canutus), Bar-tailed Godwit (Limosa lapponica), Dunlin (Calidris alpina) and Grey Plover (Pluvialis squatarola) are hardly observed on the nourished area, although these species are present in this part of the Eastern 


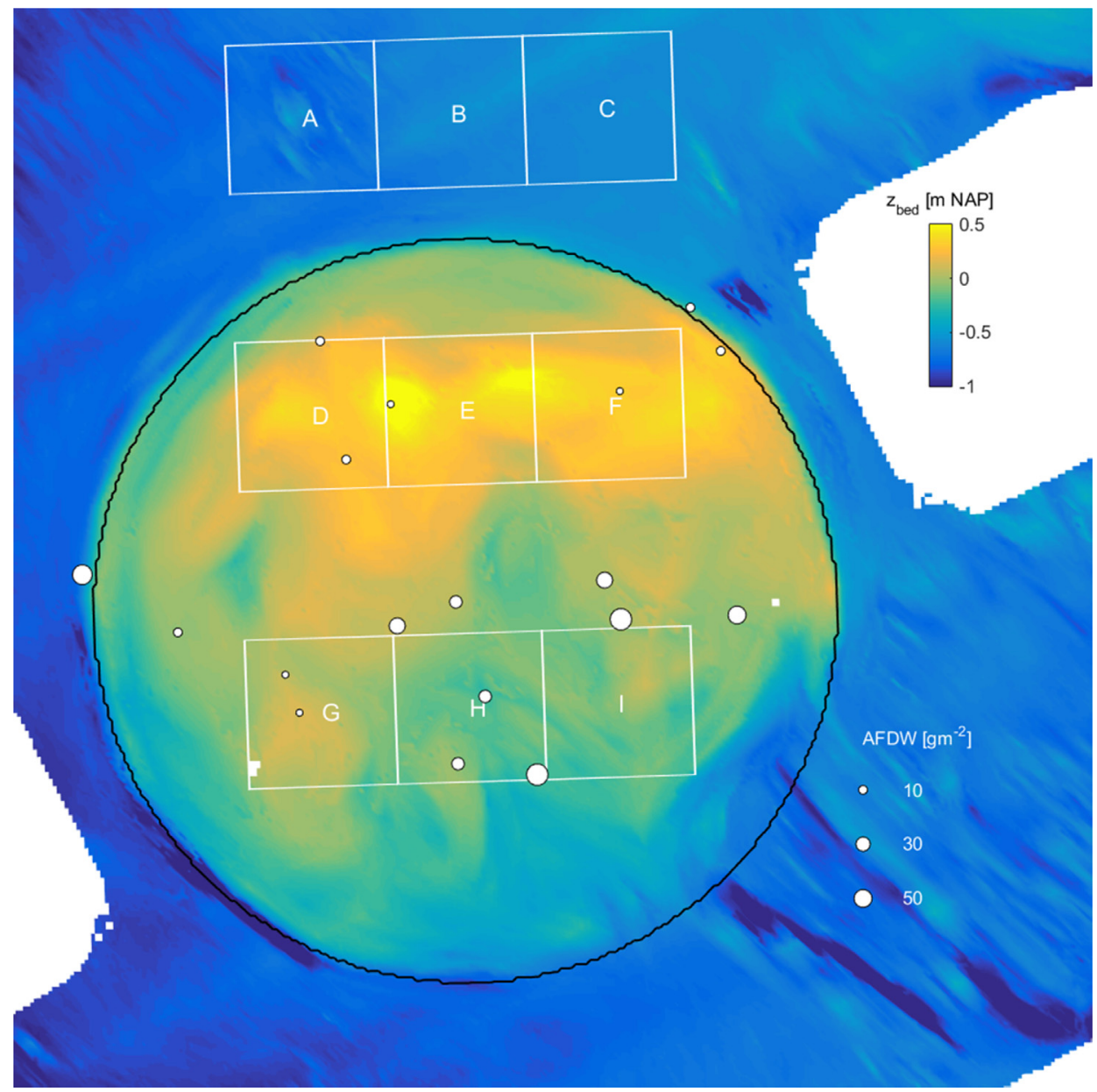

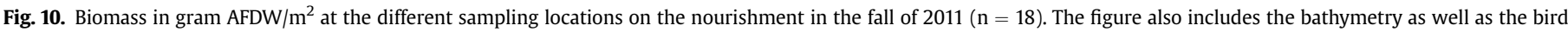
counting areas.

Scheldt. It is unknown why these waders do not make use of the nourishment. Food is abundant and of the right kind. It could be that the Galgeplaat as a whole, with an overall decreased exposure time due to the ongoing erosion, is no longer offering sufficient

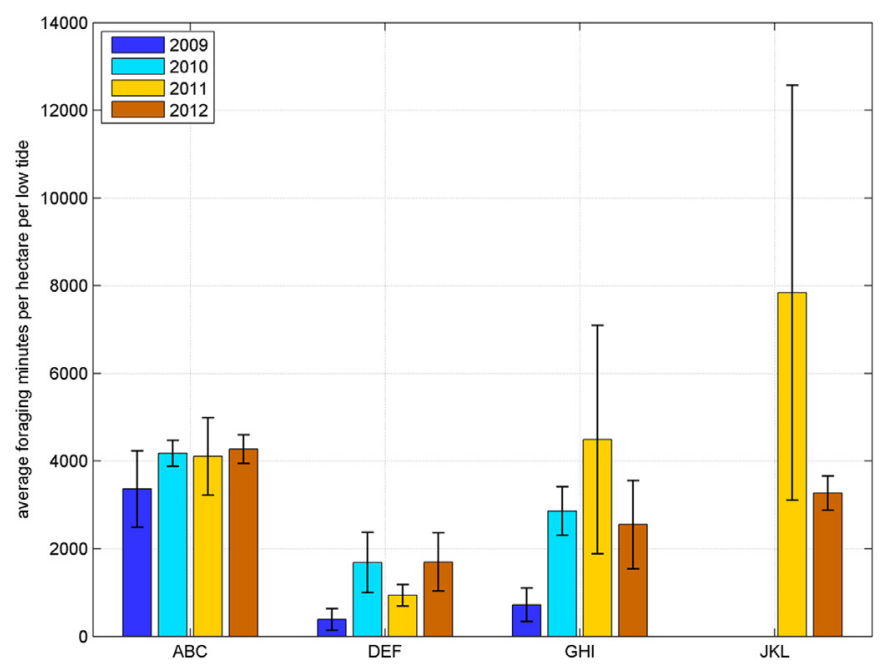

Fig. 11. Average foraging minutes per hectare per low tide for areas $A B C$ (reference), DEF (northern part nourishment), GHI (southern part nourishment) and JKL (reference). The error bars represent the standard deviation of the data. foraging time for these species. The nourishment was possibly too small ( $2 \%$ of the Galgeplaat was nourished) to change this. Insight in the numbers, dispersion and foraging behavior of these waders could provide more insight.

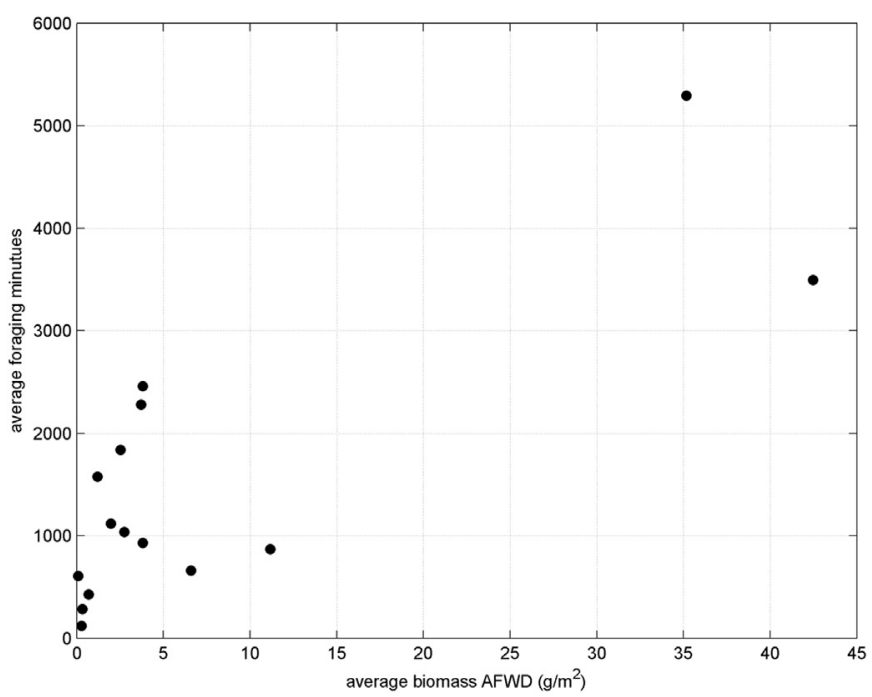

Fig. 12. The average foraging minutes per counting area as a function of the macrobenthos biomass. 


\section{Lessons learned}

The Galgeplaat nourishment pilot shows that nourishments can help to mitigate the negative effects of tidal flat erosion. The nourished sediment was relatively stable, giving time for the recovery of benthic macrofauna such that birds can benefit from the longer exposure time before the sediment has disappeared. Future monitoring should show whether the nourishment remains stable and how long the full ecological recovery will take. Application to other areas in the Eastern Scheldt or to tidal flats in other estuaries and tidal basins requires knowledge about the local hydraulic conditions (wind, tide, waves), tidal flat topography, sediment (size and mud percentage) and biological characteristics, and nourishment geometry.

On the basis of this study we conclude that sediment nourishments are an effective management measure to counteract the negative consequences of tidal flat erosion in the Eastern Scheldt. Furthermore, this "soft" sediment management approach has the advantage that it can easily be adapted to new circumstances and developments. Therefore, we recommend the Eastern Scheldt managers to continue with tidal flat nourishments in a step-by-step approach, optimising and learning along the way on the basis of high-quality monitoring data. We also believe that this potentially applies to other estuaries where distortion of the sediment cycle is causing tidal flat erosion.

\section{Acknowledgments}

This work has partly been carried out within the framework of the Deltares projects Evaluatie proefsuppletie Galgeplaat (project numbers Z4581, 1201819, 1204106, and 1206994), financed by RWS Zeeland. Furthermore, this paper uses data on the benthic community collected within the Building with Nature programme (www.ecoshape.nl). Building with Nature is funded from various sources, including the Subsidieregeling Innovatieketen Water (SIW), funded partly by the Netherlands Ministry of Infrastructure and Environment, and partly by contributions from members of the EcoShape consortium. The programme receives co-funding from the European Fund for Regional Development and the Municipality of Dordrecht.

\section{References}

Airoldi, L., Beck, M.W., 2007. Loss, status and trends for coastal marine habitats of Europe. Oceanogr. Mar. Biol. An Annu. Rev. 45, 345-405.

Baptist, M.J., Tamis, J.E., Borsje, B.W., Van der Werf, J.J., 2009. Review of the Geomorphological, Benthic Ecological and Biogeomorphological Effects of Nourishments on the Shoreface and Surf Zone of the Dutch Coast. IMARES C113/ 08, Deltares Z4582.50.

Barbier, E.B., Hacker, S.D., Kennedy, C., Koch, E.W., Stier, A.C., Silliman, B.R., 2011. The value of estuarine and coastal ecosystem services. Ecol. Monogr. 81 (2), 169-193.

Borsje, B.W., Cronin, K., Holzhauer, H., De Mesel, I., Ysebaert, T., Hibma, A., 2012. biogeomorphological interactions on a nourished tidal flat: lessons learnt on building with nature. Terra Aqua 126, 3-12.

Bouma, T.J., Van Belzen, J., Balke, T., Zhu, Z., Airoldi, L., Blight, A.J., Davies, A.J., Galván, C., Hawkins, S.J., Hoggart, S.P.G., Lara, J.L., Losada, I.J., Maza, M.,
Ondiviela, B., Skov, M.W., Strain, E.M., Thompson, R.C., Yang, S.L., Zanuttigh, B., Zhang, L., Herman, P.M.J., 2014. (2014). Identifying knowledge gaps hampering application of intertidal habitats in coastal protection: opportunities and steps to take. Coast. Eng. 87, 147-157.

Costanza, R., d'Arge, R., de Groot, R., Farber, S., Grasso, M., Hannon, B., Naeem, S., Limburg, K., Paruelo, J., O'Neill, R.V., Raskin, R., Sutton, P., van den Belt, M., 1997. The value of the world's ecosystem services and natural capital. Nature 387, $253-260$.

Cozzoli, F., Eelkema, M., Bouma, T.J., Ysebaert, T., Escaravage, V., Herman, P.M.J., 2014. A mixed modeling approach to predict the effect of environmental modification on species distributions. PLoS One 9 (2), e89131. http://dx.doi.org/ 10.1371/journal.pone.0089131.

Cronin, K., 2012. Modelling of Morphologic Effects of a Nourishment on the Galgeplaat in the Eastern Scheldt. Deltares, The Netherlands. Report 1002333.

Das, I., 2010. Morphodynamic Modelling of the Galgeplaat. University of Delft, The Netherlands. MSc thesis.

De Ronde, J.G., Mulder, J.P.M., Van Duren, L.A., Ysebaert, T., 2013. Eindadvies ANT Oosterschelde. Report 1207722-000-ZKS-0010. Deltares, The Netherlands (in Dutch).

Dyer, K.R., Christe, M.C., Wright, E.W., 2000. The classification of mudflats. Cont. Shelf Res. 20, 1061-1078.

Eelkema, M., 2013. Eastern Scheldt Inlet Morphodynamics. University of Delft, The Netherlands. PhD thesis.

Friedrichs, C.T., 2011. Tidal flat morphodynamics: a synthesis. In: Hansom, J.D., Fleming, B.W. (Eds.), Treatise on Estuarine and Coastal Science, Estuarine and Coastal Geology and Geomorphology, vol. 3. Elsevier, p. 34.

Kohsiek, L.H.M., Mulder, J.P.M., Louters, T., Berben, F., 1987. De Oosterschelde; Naar Een Nieuw Onderwaterlandschap. Report DGW.AO.87.029. RWS Dienst Getijdewateren, The Netherlands (in Dutch).

Le Hir, P., Roberts, W., Cazaillef, O., Christie, M., Bassoullet, P., Bacher, C., 2000 Characterization of intertidal flat hydrodynamics. Cont. Shelf Res. 20, 1433-1459.

Lotze, H.K., Lenihan, H.S., Bourque, B.J., Bradbury, R.H., Cooke, R.G., Kay, M.C., Kidwell, S.M., Kirby, M.X., Peterson, C.H., Jackson, J.B.C., 2006. Depletion, degradation, and recovery potential of estuaries and coastal seas. Science 312, 1806-1809.

Louters, T., Van den Berg, J.H., Mulder, J.P.M., 1998. Geomorphological changes of the oosterschelde tidal system during and after the implementation of the Delta project. J. Coast. Res. 14 (3), 1134-1151.

Nienhuis, P.H., Smaal, A.C., 1994. The Oosterschelde estuary, a case study of a changing ecosystem: an introduction. Hydrobiologia 282/283, 1-14.

Santinelli, G., De Ronde, J.G., 2012. Volume Analysis on RTK Profiles of the Eastern Scheldt. Deltares, The Netherlands. Report 1206094.

Temmerman, S., Meire, P., Bouma, T.J., Herman, P.M.J., Ysebaert, T., de Vriend, H.J., 2013. Ecosystem-based coastal defence in the face of global change. Nat. (Lond.) 504 (7478), 79-83.

Ten Brinke, W.B.M., 1993. The Impact of Biological Factors on the Deposition of Fine Grained Sediment in the Oosterschelde (The Netherlands). Utrecht University, The Netherlands. PhD thesis.

Ten Brinke, W.B.M., Dronkers, J., Mulder, J.P.M., 1994. Fine sediments in the Oosterschelde tidal basin before and after partial closure. Hydrobiologia 282/283, $41-56$.

Troost, K., Ysebaert, T., 2011. ANT Oosterschelde: Long-term Trends of Waders and Their Dependence on Intertidal Foraging Grounds. Imares. Report C063/11.

Van Dalfsen, J.A., Essink, K., 2001. Benthic community response to sand dredging and shoreface nourishment in dutch coastal waters. Senckenberg. maritima 31 (2), 329-332.

Van der Werf, J., Van Rooijen, A., Reinders, J., 2012. 3e Voortgangsrapportage Proefsuppletie Galgeplaat. Report 1204106-000. Deltares (in Dutch).

Van der Werf, J., Reinders, J., Van Rooijen, A., 2013. Evaluatie Galgeplaat Proefsuppletie 2008-2012. Report 1206994-000. Deltares (in Dutch).

Van Zanten, E., Adriaanse, L.A., 2008. Verminderd getij. Verkenning naar mogelijke maatregelen om het verlies van platen, slikken en schorren in de Oosterschelde te beperken. RWS Directie Zeeland, The Netherlands (in Dutch).

Wijnhoven, S., Escaravage, V., Blok, D., Dekker, A., Scott, T., 2012. Proef zandsuppletie Oosterschelde, Het macrobenthos van de Galgeplaat, situatie najaar 2011 en verandering sinds de aanleg. Monitor Taskforce Publication Series 2012-xx. NIOZ, Yerseke (in Dutch).

Zwarts, L., Blomert, A.M., Bos, D., Sikkema, M., 2011. Exploitation of Intertidal Flats in the Oosterschelde by Estuarine Birds. A\&W rapport 1657. 